\title{
The Case for Mandatory Separate Filing by Married Persons
}

The appropriate treatment of the personal income of married individuals is one of the most controversial areas of United States income tax policy.' Under present law, married persons aggregate their incomes on a joint return so that a married couple is treated as a single taxable unit. ${ }^{2}$ That joint filing system has two widely recognized drawbacks. First, it is not "marriage neutral," in that an individual's tax burden may vary with a change in marital status. Second, it may discourage a non-working spouse from undertaking paid employment, because it increases the marginal tax rate faced by the second earner within a couple.

A mandatory separate filing rule would both provide marriage neutrality and eliminate the second earner's disincentive. Nevertheless, joint filing has been retained beçause it appears to serve a principle of horizontal equity by ensuring that couples with equal aggregate incomes pay equal tax. That principle is premised on the belief that spouses pool their incomes and share them equally. Modern theories of marital behavior, however, indicate that that income-pooling assumption is invalid. This Note argues that married individuals retain the control and benefits of their own incomes and that therefore no principle of horizontal equity is preserved by the joint filing policy. The Note proposes the abandonment of joint filing, and suggests administratively workable rules for mandatory separate filing.

1. See, e.g., Brazer, Income Tax Treatment of the Family, in THE ECONOMics OF TAXATION 223 (H. Aaron \& M. Boskin eds. 1980) (arguing that increases in incidence of divorce and cohabitation support readoption of separate filing by married couples); McIntyre, Individual Filing in the Personal Income Tax: Prolegomena to Future Discussion, 58 N.C.L. REV. 469 (1980) (supporting retention of joint filing on equity grounds); Rosen, Is It Time to Abandon Joint Filing? 30 NAT'L TAX J. 423 (1977) (recommending separate filing on grounds of economic efficiency). Continuing controversy over the question is reflected in legislation recently passed by Congress to modify tax treatment of twoearner couples. The Economic Recovery Tax Act of 1981, Pub. L. No. 97-34, § 103, 95 Stat. 172 (August 13,1981), provides for a new deduction designed to reduce the tax burden of married couples with two earners. Although the new deduction provides some relief from the disadvantages of joint filing, see pp. 368-70 infra, significant problems remain. See 370-71 infra. For a comprehensive history of family taxation, see Bittker, Federal Income Taxation and the Family, 27 STAN. L. REV. 1389 (1975).

2. Although married couples are permitted to file separately under current law, the applicable rate schedule is so disadvantageous that only $1.3 \%$ of married couples do so. STAFF OF THE JOINT COMM. ON TAXATION, 96TH CONG., 2D SESS., REPORT ON THE INCOME TAX TREATMENT OF MARRIED COUPLES AND SINGLE PERSONS 48 (Comm. Print 1980) [hereinafter cited as JOINT COMMITTEE ON TAXATION]. Generally, married taxpayers file separately only when they are so alienated from each other that they prefer not to incur joint and several liability by signing a joint return, or when filing separately permits them to exceed the three percent of income floor for medical deductions. Id. at 9 . 


\section{The Sources of Controversy: A History of Federal Tax Treatment of Married Couples}

In a system of progressive taxation, a choice must be made between treating a married couple as two separate taxpayers or as a single taxable unit. Since 1948, federal tax policy has favored taxing a married couple as a unit even though the joint filing system creates a second earner's disincentive and thwarts the goal of marriage neutrality. Congressional dissatisfaction with joint filing has resulted in recent legislation designed to temper those effects, but both problems persist.

\section{A. The Conflict Between Marriage Neutrality and Equal Taxation of Couples}

Three conflicting goals of tax policy are implicated in the choice between taxation of a married couple as a unit or as two separate individuals. The first goal, progressivity, requires that tax burdens increase in greater than direct proportion to increases in income. ${ }^{3}$ The second goal, marriage neutrality, requires that an individual's tax burden remain unaffected by changes in marital status. " The third goal, horizontal equity be-

3. Although the question of progressivity has inspired considerable controversy, see W. BLUM \& H. KALVEN, THE UNEASY GASE FOR PROGRESSIVE TAXATION (1963), it remains a fundamental principle of the personal income tax. Hearings on the Tax Treatment of Single Persons and Married Persons Where Both Spouses Are Working, Before the House Comm. on Ways and Means, 92d Cong., 2d Sess. 78 (1972) (statement of Edwin S. Cohen, Assistant Secretary for Tax Policy, United States Dept. of the Treasury) (progressivity a fundamental premise of personal income tax) [hereinafter cited as 1972 Hearings]; G. BREAK \& J. PECHMAN, FEDERAL TAX REFORM 6 (1975) (progressive taxation choice of modern democratic societies); R. GOODE, THE INDIVIDUAL INCOME TAX 58 (prevailing sentiments demand progressivity in direct taxes); Munnell, The Couple Versus the Individual Under the Federal Personal Income Tax, in THE ECONOMICS OF TAXATION 247, 248 (H. Aaron \& M. Boskin eds. 1980) (same). Progressivity is frequently justified on the grounds that taxpayers at higher incomes can more easily pay tax on an additional dollar of income than can taxpayers at lower incomes, who must devote a greater portion of their incomes to nondiscretionary, essential expenditures. See B. BITTKER \& L. STONE, FEDERAL INCOME TAXATION 21 (5th ed. 1980) (increasing marginal ability to pay a principal justification for progressivity); R. GOODE, supra, at 18-21 (same); Munnell, supra, at 248 (same). A second justification for progressivity is that it lessens economic inequalities. See B. BITTKER \& L. STONE, supra, at 21 (progressivity sometimes justified on equalitarian principles); R. GOODE, supra, at 20 (reduction of economic inequality through progressivity helps avoid undemocratic concentrations of political power). Other justifications for a progressive personal income tax include the need to offset regressive excise and indirect taxes, id. at 58 , and the possibility that high-income taxpayers receive a disproportionately large share of the benefits of governmental expenditures, J. WINFREY, PUBLIC FinANCE 316 (1973).

4. Concern for marriage neutrality originally focused on the need to avoid a marriage penalty, because "society places a high value on marriage and the family." Thorson, An Analysis of the Sources of Continued Controversy Over the Tax Treatment of Family Income, 18 NAT'L TAX J. 113, 122 (1965). The marriage penalty problem remains a primary source of dissatisfaction with joint filing, see S. REP. No. 97-144, 97th Cong., 1st Sess. 12, reprinted in [1981] U.S. CODE CONG. \& AD. NEwS 191 (marriage penalties imply "lack of concern on the part of the government for the family") [hereinafter cited as SENATE REPORT]; Gerzog, The Marriage Penalty: The Working Couple's Dilemma, 47 FORDHAM L. REV. 27, 36 (1978) (disincentives for marriage undesirable); McIntyre, supra note 1, at 477 (marriage penalty "unhappy feature" of joint filing). Many recent commentators also protest the existence of any marriage "bonus." See, e.g., Bittker, supra note 1, at 1395 (state should 
tween married couples, ${ }^{5}$ requires that couples with equal aggregate incomes pay equal tax.

Unfortunately, it is impossible to design a system of personal income taxation that meets all three goals. ${ }^{6}$ The conflict can be illustrated by an example involving four taxpayers: $\mathrm{A}$ and $\mathrm{B}$ who each earn $\$ 10,000$ annually, C who earns $\$ 20,000$, and D who has no income. Under a progressive income tax that taxes all income above $\$ 10,000$ at a rate of fifty percent, and leaves all income below that level untaxed, $G$ will pay $\$ 5,000$ in tax annually, while $A, B$, and $D$ pay no tax. If $A$ marries $B$, and $C$ marries $D$, marriage neutrality demands that $A$ and $B$ continue to pay no tax, while $C$ and $D$ pay $\$ 5,000$. Yet equal taxation of couples demands that both couples pay the same tax.

Because progressivity is considered a fundamental principle of federal income tax policy, any system for the taxation of married couples must preserve it. ${ }^{7}$ Thus, the conflict among tax goals reduces to a choice between taxation of the couple as a unit, which permits both progressivity

neither encourage nor discourage marriage through tax incentives or penalties); Brazer, supra note 1, at 229 (personal income tax inappropriate instrument for penalizing those who do not choose heterosexual wedlock blessed by civil or religious authority).

5. Horizontal equity entails similar tax treatment of individuals in similar circumstances; in contrast, vertical equity concerns suitable distinctions between taxpayers in admittedly different circumstances. Questions of vertical equity arise primarily when determining the different tax burdens that should be borne by taxpayers at different income levels under a progressive system. See G. BREAK \& J. PEChMan, supra note 3, at 5-7.

6. Mathematical proof of the logical inconsistency among progressivity, marriage neutrality, and equal taxation of couples can be shown as follows:

Assume that $A$ and $B$ have equal incomes, $C$ has an income equal to the combined income of $A$ and $B$, and $D$ has no income. Let $T(A), T(B), T(C)$, and $T(D)$ be the tax burdens of the respective individuals. $A$ progressive tax system requires that:

(1) $T(C)>T(A)+T(B)$.

Now assume that A marries B, and $C$ marries D. Equal taxation of couples demands that:

(2) $\mathrm{T}(\mathrm{AB})=\mathrm{T}(\mathrm{CD})$.

Marriage neutrality demands that:

(3) $T(A)+T(B)=T(A B)$

and that:

(4) $T(C)=T(C D)$.

Substituting equations (3) and (4) into (2) yields:

$T(A)+T(B)=T(C)$,

which contradicts progressivity equation (1).

JOINT COMMIITTE ON TAXATION, supra note 2 , at 26 n.1.

7. See note 3 supra. Although some degree of progressivity is considered fundamental to the income tax, there is disagreement about the most appropriate rate, especially in light of recent rates of inflation. As part of the Economic Recovery Tax Act of 1981, Pub. L. No. 97-34, § 101, 95 Stat. 172 (August 13, 1981), the rate schedules for individual taxpayers were revised to reduce overall progressivity somewhat by reducing the $70 \%$ maximum rate on individual income to $50 \%$ by 1984 . SENATE REPORT, supra note 4 , at 26 . Because of the relationship between progressivity and marriage neutrality, this "flattening" of the progressive schedule has in turn reduced the marriage bonus or penalty a couple may face. See note 6 supra. 
and equal taxation of couples, and taxation of the couple as two separate individuals, which preserves progressivity and marriage neutrality.

\section{B. The Adoption of Joint Filing}

Prior to 1948 , married persons and single persons were taxed alike as separate individuals under a single rate schedule. ${ }^{9}$ Married couples who lived in the community property states of the South and Southwest, however, were permitted to divide their income evenly between spouses and to file separate returns. ${ }^{10}$ Because this even division of income lowered a couple's tax burden under the progressive rate schedule whenever one spouse earned more than half of the couple's income, married persons in community property jurisdictions paid less tax than similarly situated married persons residing in states with common law marital rules.

In 1948, Congress eliminated that geographical disparity by permitting all married taxpayers to file joint returns that taxed family income at the same rate as if it were earned equally by two single individuals, thus extending the benefits of "income splitting" to residents of common law as well as community property states. The resulting shift in tax policy from marriage neutrality to equal taxation of couples was neither carefully considered nor consciously intended. ${ }^{11}$

8. See, e.g., 1972 Hearings, supra note 3, at 78 (statement of Edwin S. Cohen) (because progressivity is central to personal income tax, problem reduces to choice between taxation of married couples as units or as separate taxpayers); Bittker, supra note 1, at 1395-96 (expressing dilemma as choice between individual and family-unit taxation); Rosen, supra note 1, at 423-425 (same).

9. While married couples could aggregate their incomes and file a joint return prior to 1948, under a single rate schedule joint returns were usually disadvantageous. Joint filing might be preferable if a couple desired to aggregate their incomes to increase adjusted gross income on the return and raise the ceiling on allowable deductions for charitable contributions. Bittker, supra note 1 , at 1400 n.20.

10. In Poe v. Seaborn, 282 U.S. 101 (1930), the Supreme Court held that under the community property laws of the state of Washington, the wife's legal right to one-half of her husband's income had to be recognized under the then-existing tax statute. As a result, the Court concluded that the taxpayer and his wife had to be allowed to file separate returns on which each reported one-half of the family income. For further analysis of the judicial treatment of community property laws before and after Poe v. Seaborn, see Bittker, supra note 1, at 1399-1415.

11. As tax rates increased during World War II, the advantages of community property "income splitting" became more visible, and common law states began to adopt community property rules solely for their tax benefits. JOINT COMMITTEE ON TAXATION, supra note 2, at 22-23. In 1948, spurred by the prospect of widespread adoption of community property laws, Congress considered various solutions to the geographical disparities in tax rates. The extension of income-splitting benefits to married couples in common law states enjoyed great support for three reasons: First, it was not politically feasible to deprive residents of community property states of the income-splitting advantages they had so long enjoyed. Bittker, supra note 1, at 1412. See H. GROVES, FEDERAL TAX TREATMENT OF THE FAMILY 63 (1963) (vehement opposition of community property states prevented passage of 1941 legislation attributing community property income to actual carner for federal tax purposes). Second, many Congressmen supported a tax cut opposed by the President, and thought the support of community property states for a tax bill incorporating income splitting would aid passage over a Presidential veto. Id. at 64-65; Oldman \& Temple, Comparative Analysis of the Taxation of Marrried Persons, 12 STAN. L. REV. 585, 593-94 (1960) (same). Third, extension of the benefits of income splitting to married couples in common law states allowed Congress to claim the political credit that 


\section{The Defects of Joint Filing}

The adoption of the new joint return in 1948 permitted a tax reduction for individuals who married, unless their incomes were already earned so equally that income splitting provided no benefit. Congress came to regard this marriage "bonus" as excessive, ${ }^{12}$ particularly because married couples were perceived as enjoying economies of scale in the purchase of food, housing, and other goods and services. ${ }^{13}$ Congress' desire to reduce the marriage bonus led in 1969 to the adoption of a new schedule of tax rates that limited a single person's tax liability to no more than $120 \%$ that of a married couple with the same income. ${ }^{14}$

The adoption of the new singles' schedule has created its own problems. For the couple whose income is earned primarily by one partner, tax liability is still reduced upon marriage. But a married couple whose income is earned equally by each spouse now suffers an increase in tax burden under joint filing. To prevent such couples from filing separately to take advantage of the 1969 singles' schedule, Congress provided that married couples filing separate returns must be taxed under the old singles' schedule, now the most disadvantageous of all. ${ }^{15}$ The changes in 1969 thus reduced the marriage bonus at the cost of creating a new marriage penalty. The present joint filing system is consequently characterized by an arbitrary system of incentives and disincentives for marriage that are determined by a couple's income and the proportions in which that income is

would otherwise have gone to the state legislatures, which were rapidly adopting community property laws in previously common law states. Bittker, supra note 1, at 1413. The need for a politically feasible solution to the geographical disparities in taxation arising out of Poe v. Seaborn thus led to a radical but largely unintended shift away from marriage neutrality toward equal taxation of couples. See H. GROVES, supra at 17 (income splitting on joint return product of historical developments rather than design; resulting bizarre changes in preexisting tax distribution probably neither carefully weighed nor consciously intended); Bittker, supra note 1, at 1416 (enactment of joint filing system occurred without discussion of effects on marriage neutrality); Oldman \& Temple, supra, at 593 (adoption of income-splitting joint return probably product of political expediency rather than conscious policy decision to reallocate tax burden).

12. By 1969 , a single individual might pay as much as $42 \%$ more tax than a married couple with the same income. JOINT COMMITTEE ON TAXATION, supra note 2, at 23 . Congress regarded this disparity as too great. Id.

13. While two may not live as cheaply as one, it was argued, a married couple could still live more cheaply than two single individuals; for example, apartments could be shared and one newspaper or autombile would do instead of two. Bittker, supra note 1, at 1422-25. Some commentators suggest, however, that the argument that married couples enjoy economies of scale that single persons do not is problematic, because single persons also have the option of living in a household with family members or other individuals. H. GROVES, supra note 11, at 94 n.2; Pechman, Income Splitting, in H. STEIN \& J. PECHMAN, ESSAYS IN FedeRAL TAXATION 49, 55-56 (1959); Surrey, Family Income and Federal Taxation, 24 TAXEs 980, 985 (1946). In fact, most singles do share households. See Gerzog, supra note 4 , at 35 (62.5\% of single persons share their homes with another).

14. Tax Reform Act of 1969, Pub. L. No. 91-172, 83 Stat. 487 (1969).

15. Rosen, supra note 1 , at 427 . Separate filing by married persons still may be advantageous under limited circumstances. See note 2 supra. 
earned by each spouse. ${ }^{16}$ While there is no evidence as to the number of taxpayers who have actually refrained from entering marriage or who have sought divorce solely for tax reasons, the amounts of tax liability involved can be considerable. For a couple whose total income in 1979 was $\$ 50,000$, marriage could result in an annual tax bonus of $\$ 3,344$ or an annual tax penalty of $\$ 2,674$, depending on the percentage of joint income earned by each spouse. ${ }^{17}$ That marriage penalty has resulted in some well-publicized cases of happily married couples who obtained annual "tax divorces." ${ }^{18}$ Even if the effects of joint filing do not extensively influence most taxpayers' behavior, the existence of penalties and bonuses for marriage has been widely criticized as an arbitrary and undesirable government intrusion into private activity. ${ }^{19}$

A second major disadvantage of joint filing is the creation of a second earner's disincentive. Joint filing discourages a non-working person with a working spouse from employment, because his first dollar earned will be taxed at the same high marginal rate as the last dollar earned by the couple's primary earner. ${ }^{20} \mathrm{~A}$ second earner within a couple must also sac-

16. As a general rule, marriage will increase a couple's tax burden whenever the lesser-carning spouse earns $20 \%$ or more of the couple's total income, and decrease a couple's tax burden whenever the lesser-earning spouse earns less than 20\%. Gerzog, supra note 4, at 28. See also JOINT COMMIIT. TEE ON TAXATION, supra note 2, at 29 (table of effect of marriage on individual's tax liability according to family income and percentage of family income earned by lesser-earning spouse). The magnitude of the marriage penalty or bonus may also be affected by the number of dependents in the household; in 1951, Congress enacted the Head of Household (HOH) rate schedule, which gives unmarried or divorced taxpayers supporting dependents half the income-splitting benefits of joint filing. That is, it taxes their returns at a rate midway between that applied to a married couple's joint return, and that applied to a single person's return. The HOH schedule thus increases the divorce "bonus" for spouses earning equal incomes who support dependents. JOINT COMMIITEE ON TAXATION, supra note 2 , at 23,37 .

17. JOINT COMMITTEE ON TAXATION, supra note 2, at 29 (table showing effect of marriage on tax liabilities at selected income levels and earning splits between husband and wife).

18. Feld, Divorce Tax Style, 54 TAXES 608, 609 (1976); Haitch, Tax Split, N.Y. Times, Feb. 15, $1981, \S \mathrm{A}$, at 49 , col. 5 . In 1976, the Internal Revenue Service ruled that it will not recognize such divorces for tax purposes because they are "sham" transactions. Rev. Rul. 76-255, 1976-2 C.B. 40. Two taxpayers challenged the Service's position in the United States Tax Court. Boyter v. Commissioner, 74 T.C. 989 (1980). The Tax Court, however, never reached the Commissioner's argument that taxpayers' annual divorces were a sham, holding against taxpayers on the theory that the divorces were legally invalid, having been obtained in foreign courts that had no jurisdiction to grant them.

19. See, e.g., note 4 supra (original concern for marriage neutrality primarily concern to avoid marriage disincentives; recent commentators also criticize creation of incentives for only legal, heterosexual unions); Munnell, supra note 3, at 247-49 (tax burden should not vary with marital status); Richards, Discrimination Against Married Couples Under Present Income Tax Laws, 49 TAXES 526, 536-38 (1971) (same). But see McIntyre, supra note 1, at 472 (marriage penalty undesirable, but marriage bonus justifiable recognition of real changes in individual's economic circumstances that occur upon marriage).

20. In the absence of any income tax, individuals would choose to work only as long as the extra income from an additional hour of paid employment exceeds the value of an additional hour of leisure time. Income taxes reduce an individual's net wage, creating incentives to work longer hours to maintain previous levels of consumption (the "income effect"). They also create incentives to work shorter hours, by increasing the value of leisure time relative to the individual's declining net wage (the "substitution effect"). Because the income and substitution effects conflict, the overall impact of taxes 
rifice time that otherwise might be spent providing household and childcare services, which are not taxed as imputed income. ${ }^{21}$ Further, second earners entering employment face additional nondeductible work-related expenses.

With the growing acceptance of two-earner couples, ${ }^{22}$ the possible economic inefficiency ${ }^{23}$ associated with the second earner's disincentive has become a source of increasing concern. ${ }^{24}$ Further, because most second earners are married women, ${ }^{25}$ the disincentive is also criticized for rein-

on the number of hours spent in paid employment depends on the relative strengths of these effects. Studies of the labor force participation of males indicate that income taxes have little effect on participation, perhaps because factors other than money play an important part in motivation. See Munnell, supra note 3, at 264 (labor force participation of adult males largely unaffected by tax rates); $c f$. Rosen, supra note 1, at 426 n.15 (increase in family income through wife's employment has little effect on husband's labor force participation). Empirical studies of the labor force participation of married women, who are generally the second earners within a married couple, see note 25 infra, suggest that their labor force participation is very sensitive to changes in their tax rate. JOINT COMMITTEE ON TAXATION, supra note 2, at 36 . Several researchers have found married women's response to a tax increase to be greater than unity; that is, a $10 \%$ decrease in net real wage due to a tax increase will result in a more than $10 \%$ decrease in the number of hours spent in paid employment. Munnell, supra note 3, at 265; Rosen, supra note 1, at 426. One commentator has criticized these studies on the ground that they measured only the marginal responses of women already in the workforce, and not the behavior of married women making the initial decision to enter employment. McIntyre, supra note 1 , at 486-87. Intuition suggests, however, that married women deciding to undertake paid employment would be even more sensitive to tax rates, because they must also face the threshold loss of their household and childcare services, and incur threshold employment-related expenses.

21. It can be argued that the disincentive associated with the loss of imputed income derives not from joint filing but from the failure of the tax system to tax imputed income from such self-performed services. Due to the difficulties that would have to be overcome to tax such imputed income fairly, however, taxation of imputed income has generally been dismissed as unfeasible. See p. 377 infra.

22. D. RICE, DUAL CAREER MARRIAGE 1-4 (1979). During the early 1940's, only about $15 \%$ to $20 \%$ of married couples contained two earners. By 1980, this figure had risen to nearly $50 \%$. Munnell, supra note 3 , at 261 .

23. Economic efficiency is achieved when individuals allocate scarce resources so as to obtain the highest possible level of satisfaction. G. BREAK \& J. PECHMAN, supra note 3 , at 7 . For example, a person will allocate his time between work and leisure in the most efficient manner by working until the income from an additional hour of employment equals his subjective value for an hour of leisure. An economically efficient tax raises revenue while minimizing the incentives for taxpayers to alter their original, efficient behavior. U.S. DEP'T OF THE TREASURY, BLUEPRINTS FOR BASIC TAX REFORM 49 (1977) [hereinafter cited as BLUEPRINTS].

24. Any income tax is inherently inefficient, because it alters the wage rewards associated with the allocation of time to paid employment. Brazer, supra note 1 , at 227 . The current use of the married couple as a single taxable unit, however, exacerbates this inefficiency. Married women are much more sensitive than men to changes in their tax rates, see note 20 supra, and much more likely to alter their employment behavior inefficiently to avoid tax. Yet married women, generally the second earners in a couple, face the greatest marginal tax rates under the joint filing system. Separate filing is consequently superior to joint filing on efficiency grounds. Brazer, supra note 1, at 227-28; Munnell, supra note 3, at 263-65; Rosen, supra note 1, at 426-27.

25. The description of married women as "second" earners is not intended to imply that their employment is somehow less important or significant than that of men. Married women are "second" earners in the sense that their employment appears to be much more discretionary; they enter or leave the market place frequently while the employment of married men remains constant. See JOINT CoMMITTEE ON TAXATION, supra note 2, at 36; Munnell, supra note 3, at 264; Rosen, supra note 1, at 426 . 
forcing sexual stereotypes by encouraging married women to remain at home producing more traditional household and childcare services. ${ }^{26}$

\section{The Second Earner's Deduction}

Concern over both the second earner's disincentive and the marriage penalty has induced Congress to write still another chapter in the history of the federal tax treatment of married couples. The Economic Recovery Tax Act of 1981 permits married couples with two earners a new tax deduction based on the earnings of the lesser-earning spouse. ${ }^{27}$ In 1982, married couples filing joint returns will be allowed to deduct from their taxable income five percent of the lesser of $\$ 30,000$ or the earned income of the lesser-earning spouse. For 1983 and subsequent years, the deduction will be ten percent. ${ }^{28}$

While the deduction provides some relief from the undesirable effects of joint filing, it stops far short of achieving marriage neutrality or eliminating the second earner's disincentive. First, the deduction does not reduce the tax bonus enjoyed by married persons whose incomes are relatively unequal. ${ }^{29}$ Second, while the deduction reduces the marriage penalty paid by married individuals with relatively equal incomes, significant penalties still remain. For a couple whose total income in $1984^{30}$ is $\$ 50,000$, marriage could result in an annual tax penalty of $\$ 1,142 .^{31}$ Third, the deduction does not eliminate the second earner's disincentive. For example, an unmarried person undertaking employment at $\$ 15,000$ a year can expect to pay twelve percent or $\$ 1,801$ in tax in 1984 . An individual whose spouse earns $\$ 30,000$ would pay thirty percent or $\$ 4,533$ in additional tax on the same income. The new ten percent deduction would decrease that

26. See Bittker, supra note 1 , at 1433 (reasonable to describe joint filing system as biased against married women); Gerzog, supra note 4, at 36-37 (joint filing reinforces stereotypical notions of married women's appropriate roles).

27. Economic Recovery Tax Act of 1981, Pub. L. No. 97-34, § 103, 95 Stat. 172 (August 13, 1981).

28. SENATE REPORT, supra note 4, at 30 . The 1981 Act also contains provisions that "flatten" the rate schedules by reducing the marginal tax rates faced by high-income taxpayers. Because of the relationship between progressivity and marriage neutrality, these rate reductions, which will be phased in fully by 1984, also reduce slightly the second earner's disincentive and the tax penalties or bonuses associated with marriage. See note 6 supra.

29. In fact, where a couple has two earners (and therefore qualifies to take the deduction) but more than $80 \%$ of joint income is earned by one spouse (so that the couple already enjoys a marriage bonus, see note 16 supra), the deduction will increase the amount of that bonus.

30. 1984 figures are used to incorporate fully the effects of the rate reductions provided by the Economic Recovery Tax Act of 1981, Pub. L. No. 97-34, § 101, 95 Stat. 172 (August 13, 1981).

31. These calculations are derived from the 1984 rate schedules provided in the Economic Recovery Tax Act of 1981, Pub. L. No. 97-34, $\S 101,95$ Stat. 172 (August 13, 1981), and assume that the taxpayers do not itemize and have no dependents. Under the same assumptions, a couple with a joint income of $\$ 15,000$ could face a tax bonus of $\$ 338$ or a tax penalty of $\$ 71$ upon marriage; a couple with a $\$ 30,000$ income could face a $\$ 1,458$ bonus or a $\$ 731$ penalty; and a couple with a $\$ 100,000$ income could face a $\$ 5,935$ bonus or a $\$ 3,280$ penalty. 
tax bill only to $\$ 4,038$, or twenty-seven percent of the second earner's income. ${ }^{32}$

\section{The Problem of Horizontal Equity}

Despite the widely recognized drawbacks of joint filing, ${ }^{33}$ no commentator has advocated its abandonment until very recently. ${ }^{34}$ The continuing popularity of joint filing arises from the belief that it is more important to

32. Again, these calculations are from the 1984 rate schedules provided in the Economic Recovery Tax Act of 1981, Pub. L. No. 97-34, § 101, 95 Stat. 172 (August 13, 1981), and assume taxpayers do not itemize and have no dependents. Under those assumptions, a taxpayer whose spouse earns $\$ 15,000$ would pay a tax of $20 \%$ on an additional $\$ 15,000$ in earnings, and use of the new deduction would reduce this rate only to $17 \%$. A taxpayer undertaking employment at $\$ 25,000$ a year, who would pay $17 \%$ tax on that income if unmarried, would pay $30 \%$ tax if his spouse also earned $\$ 25,000$ (a rate reduced to $26 \%$ by the new deduction) and would pay $40 \%$ tax if his spouse earned $\$ 50,000$ (a rate reduced only to $36 \%$ by the deduction).

33. See, e.g., JOINT COMMITTEE ON TAXATION, supra note 2, at 26-37; G. BREAK \& J. PECHMAN, supra note 3 , at 32-36. In the past, numerous proposals have been suggested to remedy, at least partially, the defects of joint filing. The 1976 childcare credit, I.R.C. $\S 44 \mathrm{~A}$, is designed to compensate for the loss of childcare and household services that occurs when both spouses are employed, and is available only to two-earner couples and single persons who incur expenses for care of a dependent in order to undertake paid employment. Other suggested proposals included a limited deduction or credit of some percentage of the earnings of the lesser-earning spouse. See JOINT COMMITTEE ON TAXATION, supra note 2, at 6-7. Somewhat similar is the "Pechman plan," under which married couples would file joint returns taxed at the same rate as unmarried individuals' returns, but would receive in addition a special deduction or credit based on the earnings of the lesser-earning spouse. J. PECHMAN, FEDERAL TAX POLICY 95-97 (3d ed. 1977). Another proposal would permit married couples to file separate returns under the 1969 singles' schedule, if they perceive such filing to be advantageous. JOINT COMMITTEE ON TAXATION, supra note 2, at 6; Gerzog, supra note 4, at 4748. A nonprogressive, flat-rate income tax with a per-taxpayer refundable credit also has been proposed. Such a system would provide for equal taxation of couples with equal incomes, marriage neutrality, and some limited progressivity. JOINT COMMITTEE ON TAXATION, supra note 2, at 7; Rankin, Plans to Ease the Marriage Levy, N.Y. Times, Sept. 9, 1980, § D, at 2, col. 3.

In fact, none of these proposals completely remedies the defects of joint filing. A deduction or credit based on the earnings of the lesser-earning spouse fails to acheive complete marriage neutrality or elimination of the second earner's disincentive. See p. 369 supra (failure of deduction provided by the Economic Recovery Tax Act of 1981, Pub. L. No. 97-34, § 103, 95 Stat. 172 (August 13, 1981), to acheive these goals). Permitting married couples the option of filing separately under the 1969 singles' schedule would eliminate the marriage penalty, but a marriage bonus would persist for those couples whose income was earned disproportionately enough that joint filing was still advantageous, and the second earner's disincentive would persist for these couples as well. Given the importance of progressivity to the personal income tax, see p. 364 supra, elimination of this fundamental principle seems a visionary approach to the problems of marriage neutrality and the second earner's disincentive. Gerzog, supra note 4, at 44.

34. Rosen, supra note 1, who recommended mandatory separate filing in 1977 on grounds of economic efficiency, appears to be the first commentator to suggest seriously a return to the individual tax unit. More recent champions of mandatory separate filing include Brazer, supra note 1, and Munnell, supra note 3, both of whom suggest that increases in cohabitation, employment of married women, and divorce incidence have made the individual tax unit more attractive. 


\section{ensure that married couples with equal incomes pay equal tax ${ }^{35}$ than to avoid variations in individual tax liability based on marital status. ${ }^{36}$ \\ That belief is premised, however, upon an assumption that married persons pool incomes. ${ }^{37}$ The concept of income pooling, while widely ac- cepted ${ }^{38}$ remains without empirical support. ${ }^{39}$ In fact, modern studies of}

35. See JOINT COMMITTEE ON TAXATION, supra note 2, at 26-28 (joint filing premised on desirability of equal taxation of couples); McIntyre, supra note 1 , at 470-71 (equity demands that couples with equal incomes bear equal tax burdens). Even Munnell, who supports mandatory separate filing, believes that the need for equal taxation of couples presents the "most serious" objection to separate filing. Munnell, supra note 3, at 278. Nevertheless, many of the recent proposals to remedy the defects of joint filing would also compromise the principle of equal taxation of couples. For example, the second earner's deduction recently adopted by Congress, see p. 370 supra, will ensure that two-earner couples pay less tax than one-earner couples with the same joint income. Because the benefit of that proposal increases in direct proportion to the second earner's income, couples whose incomes are earned equally by each spouse will also pay less tax than other two-earner couples with the same aggregate income, earned less evenly by each spouse. This would also be true for couples who file separately under an optional separate filing scheme. Interestingly, these equity effects have not provoked much comment. One commentator, however, has noted the detrimental effect of optional separate filing on the equal taxation of couples. See Gerzog, supra note 4, at 44-45.

36. Secondarily, joint filing provides an easy solution to the administrative problem of policing tax avoidance through interspousal transfers of income-producing assets and credits, deductions, and exemptions. Because income and deductions are attributed to the couple as a unit, allocation between spouses is irrelevant. Joint filing also solves the pre-1948 problem of geographical disparities in the tax treatment of married couples in community property and common law states, by extending the benefits of Poe v. Seaborn, note 10 supra, to all married couples. These geographical disparities, however, can also be easily eliminated under mandatory separate filing by a statutory override of community property laws for purposes of federal income taxation. See note 60 infra.

37. SENATE REPORT, supra note 4, at 29 (equal taxation of couples appropriate because married couples frequently pool incomes and consume as unit); JOINT COMMITTEE ON TAXATION, supra note 2, at 27 (attractiveness of principle of equal taxation of couples depends on extent to which spouses pool incomes and single individuals do not); McIntyre, supra note 1, at 470 (reality or perceived reality of marital pooling is underpinning for joint filing); Thorson, supra note 4, at 116 (income pooling implies married couple is appropriate taxable unit).

It should be noted that the tax system's recognition of pooling behavior through joint filing has itself been criticized as a source of horizontal inequity between similar households because children, dependent parents, cohabitating couples and homosexual companions may also pool incomes. Income could be split on a joint return not only between husband and wife, but among other household members as well. While even the supporters of joint filing have recognized that marriage is not a necessary condition for pooling, see Bittker, supra note 1, at 1398-1400; McIntyre, supra note 1, at 480 , the restriction of the income-splitting benefits of the joint return to married couples has been justified as an easily administered "bright line" test for pooling arrangements. Nevertheless, a proposal to permit income splitting among family members in addition to spouses was suggested in 1946 by Surrey, then Tax Legislative Counsel to the Secretary of the Treasury. See Surrey, supra note 13, at 986 .

Joint filing has also been criticized as a source of horizontal inequity between similar couples because it does not account for the real benefits that one-earner couples enjoy over two-earner couples with the same income, due to the household and childcare services a nonworking spouse can provide and the absence of an additional set of nondeductible employment-related expenses. See, e.g., Bittker, supra note 1, at 1425-26; Brazer, supra note 1, at 242; Gerzog, supra note 4, at 33 . Those differences between one- and two-earner couples may persist beyond the initial entrance of the second earner into employment. Thorson, supra note 4 , at 116-17. As the income of the lesser-earning spouse rises, it is likely that his employment expenses will rise as well. Similarly, less time is available for the provision of untaxed household services; at lower income levels, second earners are often employed in part-time positions. With the recent rise in the representation of two-earner couples, see note 22 supra, this inequity between one- and two-earner couples has become a greater source of concern.

38. See McIntyre, supra note 1 , at 471 (no serious challenges have been made to assumption of widespread marital pooling). Even the supporters of mandatory separate filing have not challenged the income pooling assumption. See, e.g., Brazer, supra note 1, at 226; Munnell, supra note 3, at 247-48; 
the family suggest that married persons retain the control and benefits of their personal incomes. Concern for horizontal equity in personal income taxation is therefore better served by taxing individual rather than joint income.

\section{A. Marital Income Sharing Patterns: Pooling or Exchange?}

Under the joint filing system, income splitting is usually justified by the assumption that, while a greater-earning spouse may have legal possession of his income, the actual control and benefits of the income will be shared equally by both spouses. ${ }^{40}$ Because family consumption decisions are presumed to be joint decisions, both spouses are perceived to gain an equal benefit from an increase in family income regardless of which spouse earns it.

But exchange theory, one of the dominant modern perspectives on social behavior, ${ }^{41}$ suggests that married individuals do not enjoy access to their

Rosen, supra note 1, at 425 . Rather than questioning the pooling presumption, these authors have argued that the need for horizontal equity between couples is outweighed by other considerations. See note 34 supra. Pechman also accepts the premise of income pooling, but objects to the income-splitting benefits of joint filing on the ground that the decision to marry and pool income is voluntary, and should be ignored for tax purposes just like any other consumption decision. Pechman, supra note 13, at 55 .

39. H. GROVES, supra note 11, at 70; McIntyre, supra note 1, at 469 . Thorson claims to have discovered a "consensus" that married couples pool income, but he gives no empirical support for this finding. Thorson, supra note 4, at 116. Even commentators who accept the pooling presumption note that pooling may not occur between high-income spouses. H. GrovES, supra note 11, at 70; Bittker, supra note 1, at 1394; Thorson, supra note 4, at 116. Yet the benefits of income splitting are greatest for high-income couples, because low-income taxpayers are already taxed at such low rates that income splitting makes little difference; for example, a one-earner couple filing a joint return with an income of $\$ 5,000$ enjoys a marriage bonus of $\$ 250$, or $5 \%$ of after-tax income, while a one-earner couple with an income of $\$ 50,000$ enjoys a marriage bonus of $\$ 3,344$, or $9.2 \%$ of after-tax income. JOINT COMMITTEE ON TAXATION, supra note 2, at 29 (table showing effect of marriage on tax liability in dollar amounts at selected income levels and earnings splits between husband and wife), id. at 30 (table showing effect of marriage on tax liability as percentage of family income, at selected income levels and earnings splits between husband and wife).

40. See Bittker, supra note 1, at 1420-21 (married person has less legal, emotional, and social control over his income); McIntyre, supra note 1, at 475-76 (to tax primary earner in couple on his full income is to tax "potential" rather than actual income, and is inconsistent with principle of taxing income to individual with control or enjoyment of income); Thorson, supra note 4, at 116 (technical title over income does not indicate actual control or benefits that accrue to married taxpayer).

41. Although "some variant of the rational choice [exchange theory] approach has long been with us," A. HEATH, RATIONAL ChoICE AND SOCIAL EXCHANGE 184 (1976), modern American exchange theory has its roots in two seminal works: P. BLAU, EXCHANGE AND POWER IN SOCIAL LIFE (1964), and G. HOMANS, SOCIAL BEHAVIOR: ITS ELEMENTARY FORMS (1961). While exchange analysis is a relatively recent development in sociological theory, it has gained widespread appeal. It was regarded as an emerging perspective as recently as the early 1970's. W. GOODE, EXPLORATIONS IN SOCIAL THEORY 98-99 (1973) (noting "the many 'exchange theories' that have been developed of late"); Spengler, Contemporary Approaches to Societal Analysis, in THEORETICAL SOCIOLOGY 486 (J. McKinney \& E. Tiryakian eds. 1970) (exchange analysis emerging field). By the late 1970's, however, exchange theory had become "one of the most prominent theoretical perspectives in sociology," $\mathrm{J}$. TURner, The Structure of Sociological THEORY 215 (rev. ed. 1978). See P. EKEH, Social EXCHANGE THEORY 81 (1974) (exchange theory major sociological perspective); A. HEATH, supra, at 184 (exchange analysis "a standard tool of the mainstream sociologist"); J. TURNER, supra, at 278 n.1 
spouse's income in a manner that would suppport the assumption of unilateral, uncompensated income transfers. ${ }^{42}$ According to exchange theory, people will not normally incur costs without expecting compensation in one form or another, so that goal-seeking individuals must exchange resources and services. ${ }^{43}$ Social relationships thus result from individuals' dependence upon the expenditures of other persons to accomplish their own goals, ${ }^{44}$ and individuals enter relationships primarily to engage in a beneficial exchange of both economic and noneconomic resources.

The resources that will be exchanged within any social relationship, including marriage, need not be economic or even similar in kind. ${ }^{45}$ When

(exchange theory has gained wide appeal in sociological theorizing). The basic theoretical principles are presented in P. BLAU, supra, and G. HOMANS, supra. For more modern syntheses of Homan's and Blau's works, see P. EKEH, supra; A. HEATH, supra; and J. TURNER, supra, at 201-309.

42. While exchange theorists do not claim that exchange is the root of all behavior, they do argue that most, if not all, social relationships can be usefully viewed as exchanges between goal-seeking individuals expecting to profit from such transactions. P. BL $\Lambda U$, supra note 41 , at 88 ("Social exchange can be observed everywhere ... not only in market relations but also in friendship and even in love."); A. HE $\Lambda$ TH, supra note 41, at 1-2 (social exchange the basis of a wide range of human relationships); G. HOMANS, supra note 41, at 13-14 (same). Exchange theory has been widely accepted as an especially useful vehicle for analysis of the marital relationship. See C. HARrIS, THE FAMILY 160 (1969) (marriage relationships maintained by exchange between partners); L. SCANZONI \& J. SCANZONI, MEN WOMEN AND GHANGE: A SOClOLOGY OF MARRIAGE AND THE FAMILY 11 (1976) ("Sociologists may look at many areas related to the family in terms of exchange theory."); E. WALSTER \& G. WALSTER, A NEW LOOK AT LOVE 135 (1978) (considerable evidence supports application of exchange theory to dating and courtship, marital choice, and marital satisfaction); R. WINCH, F - $_{\text {- }}$ MILIAL ORGANIZATION: A QUEST FOR DETERMINANTS 7, 98-100 (1977) (noting particular relevance of exchange analysis to familial behavior, and suggesting that exchange of male's hunting ability for female's childbearing and foodgathering abilities may have formed basis for first family units); Edwards, Familial Behavior as Social Exchange, 31 J. MARR. \& FAM. $521-23$ (1969) (social exchange evident in dating and mate selection research and in allocation of authority in the family decisionmaking process); Nye, Choice, Exchange, and the Family in 2 CONTEMPORARY THEORIES ABOUT THE FAMILY 1, 11-39 (W. Burr, R. Hill, F. Nye, \& I. Reiss eds. 1979) (exchange theory successfully applied to several areas of familial behavior, including labor force participation of married women, sexual behavior, marital choice and dissolution).

43. The presumption of goal-seeking rationality is central to exchange theory. People are assumed to be motivated to enter social relationships by the prospect of some return, be it psychic or economic. See P. BLAU, supra note 41, at 91-92, 98; G. HoMANS, supra note 41, at 61-62. The benefit is not always obvious; it may spring from the satisfaction of internalized norms or the approval of third parties. Nevertheless, altruism is ultimately reduced to egoism. P. BLAU, supra note 41 , at 17 . Social relationships arise when both parties stand to benefit from an exchange; that is, when each has something the other wants. See id. at 92; G. HoMANs, supra note 41, at 61; Edwards, supra note 42, at 518-19.

44. See P. BLAU, supra note 41, at 14-15; Edwards, supra note 42, at 518-19.

45. See P. BLAU, supra note 41 , at 99-100. Cf. R. BLOOD \& D. WOLFE, HUSBANDS AND WIVES 12,32 (1960) (income important resource in marital exchange); B. MURSTEIN, WHO WILL MARRY WHOM? 110-11 (1976) (physical attractiveness an exchangeable resource); L. SCANZONI \& J. SCANZONI, supra note 42, at 86, 96 (sexual intimacy exchangeable resource). Individuals who rank high on one resource scale may use their advantage to obtain a spouse who ranks high on another; an individual who is very attractive physically may use his status as a desirable companion to woo a spouse who is less attractive but has more prestige and power. B. MURSTEIN, supra, at 110-11; E. WALSTER \& G. WALSTER, supra note 42, at 139-41. The bargaining power associated with a resource depends not only on its absolute value but also on the available alternatives. See L. SCANZONI \& J. SCANZONI, supra note 42 , at 312-13. The importance of a spouse's income as a resource will be determined not only by the amount of this income but also by what the other partner might earn if he were himself to enter employment. 
both spouses earn substantial incomes, there may be no exchanges of income or property between them at all, but only exchanges of noneconomic resources such as emotional support, sexual intimacy, enhanced socioeconomic status, or the satisfaction of having fulfilled a desired social role. ${ }^{46}$ If one spouse earns more than the other, though, the greater-earning partner may transfer some of the benefits of his income to the lesser-earning spouse in return for an additional share of nonmonetary resources and services. So, for example, one spouse may exchange cash acquired through employment for household and childcare services and emotional support provided by the other spouse. ${ }^{47}$

Married individuals do not necessarily expect immediate compensation for every service provided to a spouse. According to exchange theory, however, there is a long-run expectation of reciprocity in marriage as in any other relationship. ${ }^{48}$ When selecting spouses, individuals tend to choose partners with whom they believe a marital "contract" can be arranged under which the total exchange of services will leave them better off during marriage than before. ${ }^{49}$ If an individual's exchange expectations are not fulfilled, the exchange "contract" may be renegotiated so that the relationship remains superior to other possibilities. ${ }^{50}$ One of the best documented examples of such renegotiation is the redistribution of family decisionmaking power that accompanies a change in the distribution of income or economic resources between spouses: an increase in the eco-

46. Such marriages have been described as "equal partner" arrangements, in which spouses are less concerned with providing instrumental services, such as income or household services, than with exchanging expressive resources such as companionship, emotional support, and sexual intimacy. $\mathrm{L}$. SCANZONI \& J. SCANZONI, supra note 42, at 235, 287.

47. H. ROSS \& I. SAWHILL, TIME OF TRANSITION: THE GROWTH OF FaMILIES HeAded BY WOMEN 45 (1975) (spouse who earns disproportionate amount of income "may use his position to redistribute family income in his favor, to establish greater authority within the family, or to obtain other nonmonetary perquisites"); L. SCANZONI \& J. SCANZONI, supra note 42, at 124, 260, 287, 476 (describing exchange pattern as "traditional" marriage arrangement, in which husbands seek wives to perform housekeeping services and "expressive functions" of providing comfort, support, encouragement, and respect, while wives seek husbands "who appear able to provide them with the kinds of economic security, status, and material comfort they define as acceptable").

48. Cr. P. BLAU, supra note 41 , at 16-17 (expectation of reciprocity in social relationships); $P$. EKEH, supra note 41, at 47 (same); Edwards, supra note 42, at 519 (same).

49. See C. HARRIS, supra note 42 , at 160 (marriage is contractual relationship entered after bargaining on terms); B. MURSTEIN, supra note 45, at 272-73 (exchange theory has empirical success in predicting marital choice); L. SCANZONI \& J. SCANZONI, supra note 42, at 110 (marriage decision reached only after mutually favorable implicit exchange "bargain" emerges); Edwards, supra note 42 , at 521-23 (social exchange and bargaining for resources clearly evident in dating and mate selection).

50. C. HARRIS, supra note 42 , at $160-63$ (exchange continues after marriage so that marital roles are further defined through bargaining process affected by relative power of spouses); L. SCANZONI \& J. SCANZONI, supra note 42, at 258, 321-23, 480 (marriage continual process of exchange and renegotiation under changing circumstances); E. WALSTER \& G. WALSTER, supra note 42, at 142-45 (retaining reciprocal equity of exchange important for stable relationship); cf. D. RICE, supra note 22, at 12 (wife's decision, after marriage, to pursue career produces strain between spouses that must be resolved through renegotiation or divorce). 
nomic resources that a marital partner can offer leads to a corresponding increase in that partner's control over the uses of joint income. ${ }^{51}$

Married persons generally attempt to resolve inequities in their relationship through renegotiation, because the process of divorce entails substantial economic and noneconomic costs..$^{52}$ Nevertheless, when extreme disparities in exchange cannot be reconciled, alternatives to the marriage become more attractive, and divorce more likely..$^{53}$

\section{B. The Implications of Exchange Theory for Joint Filing: The Problem of Income Attribution}

Under exchange theory, the income-splitting benefits of the joint return can only be justified as a means of recognizing that, after interspousal exchanges of resources take place, the lesser-earning spouse will have the control and benefit of approximately one-half of joint income. Yet there are two reasons to suggest that the recognition of such marital exchanges of income through joint filing is an inappropriate and undesirable means of meeting horizontal equity concerns.

First, although attribution of one-half of joint income to each spouse is consistent with the income-pooling presumption that a lesser-earning spouse has direct access to a greater-earning spouse's income, under exchange theory the greater-earning spouse retains the benefit of his income and uses it to strike a more favorable marriage "contract." Joint filing thus gives an implicit deduction to a primary earner for that part of his income that is exchanged for nonmonetary resources and services provided by his spouse. Although taxpayers are permitted to deduct expenses incurred in the production of income or the pursuit of a trade or business, ${ }^{54}$ they generally are not permitted to deduct the costs of goods and services purchased for personal consumption. ${ }^{55}$ If taxpayer expenditures for enhanced status, companionship, or household and childcare services ordina-

51. R. BLOOD \& D. WOLFE, supra note 45, at 12-13, 32 (decisionmaking power within married couples fluctuates between partners in accordance with spouses' changes in workforce participation and income); A. HEATH, supra note 41, at 105-12 (same); H. ROSS \& I. SAWHILL, supra note 47, at 42-45 (same).

52. Individuals contemplating divorce face intangible costs such as third party disapproval and the violation of internalized norms, as well as the more obvious costs of obtaining a legal agreement and facing disruption in career and living patterns. E. WALSTER \& G. WALSTER, supra note 42, at 146; Nye, supra note 42 , at 26.

53. See L. SCANZONI \& J. SGANZONI, supra note 42, at 11, 463-64 (divorce result of breakdown in renegotiation of marital exchange); E. WALSTER \& G. WALSTER, supra note 42, at 146 (inequitable exchange likely to lead to dissolution of relationship); $c f$. H. ROSS \& I. SAWHILL, supra note 47, at 41-42, 47 (wife's direct access to income through employment reduces dependency and increases attractiveness of alternatives to marriage, thereby reducing cost and increasing likelihood of divorce).

54. I.R.C. $\$ \S 162,165,212$.

55. I.R.C. $\S 262$. 
rily are not deductible,$^{56}$ a primary earner who exchanges income for such consumption goods within the marital bond should not be given a deduction for those "purchases."

Second, the services that may be provided by a lesser-earning spouse in exchange for cash income generally are not recognized as sources of income under the Internal Revenue Code. Even services that produce income when performed for a formal employer, such as childcare and household services, are not recognized as sources of income when they are performed by the taxpayer for himself or a household member. Other resources exchanged by spouses, such as emotional support, sexual intimacy, and enhanced socioeconomic status, are not freely exchanged in the marketplace, and hence are even more difficult to quantify. Because the exchange of such resources with a spouse adds to the taxpayer's well-being, they should in theory be taxed as imputed income. ${ }^{57}$ Proposals to do so have been consistently rejected, however, because of the difficulties of deciding which services to tax, the problem of measuring their value without unbearable invasions of privacy, and the fact that imputed income does not produce the actual cash needed to pay tax bills. ${ }^{58}$ Since these types of

56. The childcare credit might be viewed as an exception to this rule; however, it was not intended as a deduction for consumption expenses, but rather as a deduction for expenses incurred in the production of income (that is, paid employment). R. GOODE, supra note 3, at 156. The credit is available "only if such expenses are incurred to enable the taxpayer to be gainfully employed." I.R.C. $\S 44 \mathrm{~A}(\mathrm{c})(2)(\mathrm{A})$.

57. Imputed services might be recognized as a source of income under a "comprehensive income tax," a proposed reform that has received much support in recent years. BLUEPRINTS, supra note 23, at 1-3; COMPREhensive InCOME TAXation vii-viii (J. Pechman ed. 1977). Comprehensive income taxation involves broadening the definition of income and taxing all income alike. The Haig-Simons definition is the one most favored by specialists; it defines personal income as the market value of consumption enjoyed during the year plus the net change in savings. Goode, The Economic Definition of Income, in COMPREHENSIVE INCOME TAXATION, supra, at 7-8; McIntyre \& Oldman, Taxation of the Family in a Comprehensive and Simplified Income Tax, 90 HARV. L. REV. 1575 (1977). Under an ideal comprehensive tax system, the imputed income from leisure and services the taxpayer performs for himself would be included in the definition of "market value of consumption" and included in taxable income. One-earner couples would therefore pay more tax than two-earner couples with the same income because a nonworking spouse enjoys more free time for leisure and self-performed services. Id. at 1608. Supporters of comprehensive taxation usually reject the taxation of imputed income, however, because of the administrative difficulties. See note 58 infra. Use of a comprehensive tax base might also justify the "double taxation" of cash income transferred from a greater-earning to a lesser-earning spouse. Some have suggested this treatment for gifts and inheritances, BLUEPRINTS, supra note 23, at 48; Goode, supra, at 19-20. They argue that the beneficiary must be taxed because he clearly receives income in the form of greater consumption power, but that the donor should not be allowed a deduction because making the gift or transfer has presumably provided him satisfaction or some other element of quid pro quo, and hence is a form of consumption. Id. But see Goode, supra, at 19 (arguing under income pooling theory that family "sharing" should not be regarded as consumption); McIntyre, supra note 1, at $475 \mathrm{n.18}$ (rejecting double taxation of either shared income or gifts and inheritances, and recommending that such transfers be taxable to the beneficiary and deductible by the donor).

58. For a discussion of the difficulties of taxing imputed income, see McIntyre \& Oldman, supra note 57, at 1607-24. Most commentators reject taxation of imputed income as infeasible. See, e.g., BLUEPRINTS, supra note 23, at 7; B. BITTKER \& L. STONE, supra note 3 , at 84 ; R. GOODE, supra note 3, at 150-51; H. SIMON, PERSONAL INCOME TAXATION 53 (1938); Gerzog, supra note 4, at 34. 
services are not usually recognized as sources of income, they should not be recognized as sources of income when a lesser-earning spouse provides them in exchange for cash income earned by the greater-earning spouse.

The implications of exchange theory consequently leave little justification for joint filing on grounds of horizontal equity, since the well-being of a married taxpayer depends more upon his personal income and the pattern of exchange he has established with his spouse than on the couple's joint income. Use of joint filing to deduct consumption expenditures and tax imputed income only when they result from exchanges between married taxpayers is inequitable and arbitrary; horizontal equity is served not by imposing such treatment on a few taxpayers, but by exempting all from it. ${ }^{59}$ Mandatory separate filing is therefore preferable to joint filing on equity grounds.

\section{Administrative Obstacles to Separate Filing}

Although mandatory separate filing provides an attractive solution to the problems of marriage neutrality and the second earner's disincentive, and is preferable to joint filing on equity grounds, it presents two serious administrative problems. ${ }^{60}$ The first is determining the proper treatment

59. Treatment of alimony payments under exchange theory may depend on how such payments are viewed. If alimony is regarded as an obligation between individuals that is created and enforced by a third party-the court-alimony payments should be taxable income to the recipient (who clearly receives control and benefit of the income) and a deductible expense of the payor (whose loss can hardly be regarded as a voluntary consumption decision). This is the current approach. I.R.C. \$§ 71, 215. Alternatively, if alimony is regarded as a means of redressing the spousal exchange inequities that lead to divorce, see p. 375 supra, it should be treated neither as income to the recipient nor as a deductible expense of the payor; the transfer would not have received such treatment had it taken place, as originally intended, within the marriage. The same reasoning applies if the expectation of alimony in the event of divorce was part of the marital "contract" the spouses implicitly agreed to before marriage, see p. 374 supra.

It seems more sensible, however, to regard alimony as an obligation created by a third party. Since alimony is awarded in less than $10 \%$ of all divorce cases, see Weitzman, Legal Regulation of Marriage: Tradition and Change, 62 CALIF. L. REV. 1186 (1974), it is hardly likely to be an implicit part of the marital contract. Moreover, since alimony is usually awarded for the lifetime of either spouse or until remarriage of the recipient, Foster, Alimony Awards, in THE ECONOMICS OF DIVORCE 7 (American Bar Assoc. 1978), it is difficult to see how it might be characterized as a judicial "balancing" of existing inequities in interspousal exchange. In jurisdictions that have adopted "no-fault" divorce laws, however, alimony is sometimes made as an interim and limited award during a transition period, and the economic worth of the homemaker's contributions may be considered in determining the size of the award. Id. at 10-12. In such jurisdictions, judicial balancing of inequitable interspousal exchange may be an accurate characterization of alimony.

60. A third, more minor problem is avoiding the pre-1948 incentives for common law states to adopt community property laws in order to receive the benefits of income splitting for their residents under Poe v. Seaborn, 282 U.S. 101 (1930). This problem could readily be overcome by requiring residents of community property states to attribute earned and unearned income, for federal income tax purposes, to the spouse that actually earned the income or held title to the property that produced it. Most experts agree that there is no constitutional obstacle to such legislation. See, e.g., Bittker, supra note 1, at 1411 n.60; Munnell, supra note 3, at 272-73. But see Hall, The Working Woman and the Federal Income Tax, 61 A.B.A.J. 716, 717 (1975) (unclear whether federal statute overriding community property for tax purposes constitutional). 
of interspousal transfers of income-producing property. The second is setting the correct allocation of credits, deductions, and exemptions between spouses. Neither difficulty, however, poses an insuperable obstacle to separate filing. ${ }^{61}$

\section{A. Interspousal Tranfers of Income-Producing Property}

If separate filing is readopted, married couples will be able to reduce their overall tax liabilities by shifting the title to income-producing assets to the lesser-earning spouse. That income-splitting opportunity does not exist under joint filing, which attributes unearned income to the couple as a unit rather than to the spouse holding title to the income-producing property. Supporters of joint filing have therefore argued that a separate filing regime would favor couples enjoying significant unearned income over couples relying principally upon earned income, because only couples with unearned income could rearrange the title to income-bearing assets so that each spouse reported an equal amount of income. ${ }^{62}$

That criticism of separate filing is premised on the income pooling assumption that a transfer of title between spouses does not affect the actual benefits received by each spouse. ${ }^{63}$ Exchange theory suggests, however, that such transfers are likely to result in real changes in a spouse's economic power. ${ }^{64}$ While a transfer of title between spouses may not result in

61. Political feasibility is a different concern. Under 1979 tax rates, mandatory separate filing would result in a tax increase for about $60 \%$ of married couples, and a tax decrease for the other $40 \%$, with an overall revenue increase of between $\$ 12$ and $\$ 18$ billion. JOINT COMMITTEE ON TAXATION, supra note 2 , at 48 . Political opposition might be softened by using this revenue increase to finance an accross-the-board tax cut of between $7.8 \%$ and $5.5 \%$. Id. at 48 . The possible political appeal of mandatory separate filing is evidenced by the fact that H.R. 850, 92d Cong., Ist. Sess., 117 CoNG. REC. 191 (1971), which would have established a single rate schedule for all taxpayers regardless of marital status, was co-sponsored by 157 members of the House. 1972 Hearings, supra note 3, at 9697; Bittker, supra note 1, at 1438; Munnell, supra note 3, at 272. Two similar proposals, H.R. 108, 96th Cong., 2d Sess., 125 CONG. REC. H1054 (1980) (sponsored by Rep. Annunzio) and H.R. 2553, 96th Cong., 2d Sess., 125 CONG. REC. H1054 (1980) (sponsored by Rep. McDonald), were considered by the 96th Congress. JOINT COMAITTEE ON TAXATION, supra note 2, at 48.

62. See, e.g., DIVISION OF TAX RESEARCH, U.S. DEP'T OF THE TREASURY, THE TAX TREATMENT OF THE FAMILY, reprinted in Hearings on Community Property and Family Partnerships Before the House Comm. on Ways and Means, 80th Cong., 1st Sess., pt.2, at 849, 850 (1947) (hereinafter cited as TAX TRE八TMENT OF FAMILY INCOME]; Bittker, supra note 1, at 1440-41; Oldman \& Temple, supra note 11, at 600-01; Surrey, supra note 13, at 983-84.

63. TAX TREATMENT OF FAMILY INCOME, supra note 62, at 867 (inequity argument presumes that original owner may retain control over asset and income by virtue of personal relationship with new owner); Rosen, supra note 1, at 425 (fear of inequity implicilly presumes that property rights irrelevant within family); Surrey, supra note 13, at 985 (inequity perception premised on assumption that family is economic unit of consumption).

64. While one spouse may transfer assets to the other, perhaps in exchange for some other resource or service, under exchange theory the donee spouse can generally be expected to be aware that title and legal control have changed, and to use this new economic resource in bargaining. Many of the interspousal transfers that were a source of concern prior to 1948 were designed to shift investment income without shifting ownership or control, Bittker, supra note 1, at 1441, which suggests that most married taxpayers are reluctant to transfer property rights simply for tax avoidance reasons. 
as complete a transfer of the control and benefits of income-producing property as a transfer of title between parties dealing at arm's length, ${ }^{65}$ it is comparable to a gift of income-producing assets to an adult child or other relative, and it deserves the same tax recognition. ${ }^{66}$

Admittedly, recognition of interspousal transfers would probably increase taxpayer attempts to accomplish "sham" transfers ${ }^{67}$ designed to reduce tax liability without actual transfer of title. Although the tax administration must already deal with sham transfers between parents, children, and other household members, the adoption of separate filing would add the burden of policing interspousal transfers as well. ${ }^{68}$ But any alternate arbitrary rule of allocation, such as attribution of all the couple's unearned income to the spouse with the greatest earned income, or allocation between spouses in proportion to earned incomes or on a fifty-fifty basis, might result in changes in a couple's tax burden upon marriage. ${ }^{69}$ In the absence of evidence suggesting that the cost of policing interspousal transfers would greatly exceed the cost of policing other interfamilial

With recent increases in the divorce rate, see Munnell, supra note 3, at 265-66 (divorce rates more than doubled between 1966 and 1978, from 2.5 per 1,000 to 5.1 per 1,000 annually; among younger taxpayers, estimated that more than one-third of married persons between ages 25 and 35 in 1975 will end first marriage in divorce), married individuals have even greater incentive not to transfer property rights solely to lessen tax liabilities. Even before the recent increases in divorce, Treasury studies of 1957 and 1959 tax returns reported that high-income taxpayers did not take full advantage of property transfers to minimize their federal estate and gift tax liability. Id. at 273 n.37.

65. The economic and psychic costs associated with divorce may induce a donee spouse to adhere to an implicit interspousal bargain to transfer assets for tax purposes only, although the donce spouse seems likely to demand at least a portion of the tax benefits that result. It is also possible that a naive spouse might be unaware of the change in legal rights that accompanies a transfer in title, so that the donor retains control and benefit of the asset. These factors are present when other interfamilial transfers are made, however, although perhaps to a lesser degree.

66. Under present law, income from property is generally taxable to whomever holds legal title, even when the property was received as a gift from a family member. See B. BITTKER \& L. STONE, supra note 3 , at $415-500$.

67. See, e.g., Helvering v. Horst, 311 U.S. 112 (1940) (taxpayer gave his son interest coupons from bond); Helvering v. Clifford, 309 U.S. 331 (1940) (taxpayer created trust but retained control over income with corpus to revert to taxpayer in five years); Corliss v. Bowers, 281 U.S. 376 (1930) (taxpayer retained power to revoke or modify trust).

68. There appears to be little consensus on how unwieldy a tax system that recognized interspousal transfers would be. Compare JOINT COMMITTEE ON TAXATION, supra note 2, at 47-48 (recognition desirable for marriage neutrality, but would increase administrative complexity) and Brazer, supra note 1, at 243 (same) with Rosen, supra note 1, at 428 (recognition probably not too burdensome). There was similar uncertainty in 1948. Compare Surrey, supra note 13, at 981 (suggesting in 1946 that amount of litigation surrounding sham interspousal transfers had reached "unhealthy" level) with H. GROVES, supra note 11, at 63 (suggesting that concern for interspousal transfers only minor motivation for 1948 adoption of joint filing system).

69. Any rule that allocated unearned income between spouses without regard for actual title would violate marriage neutrality because a couple's tax burden might increase or decrease upon marriage, depending on which spouse has actual title and the proportions in which each earned other income. $\Lambda$ rule that attributed unearned income from an asset to the spouse who actually held title to the asset at the time of marriage, with no recognition of later transfers, would violate marriage neutrality by prohibiting recognition of subsequent transactions that would have been recognized if they had occurred before, or outside of, marriage. 
transfers of assets, the additional administrative burden is probably a price worth paying to ensure marriage neutrality. ${ }^{70}$

\section{B. Interspousal Transfers of Credits, Deductions, and Exemptions}

Under mandatory separate filing, the allocation of credits, deductions, and exemptions between spouses will greatly affect tax burdens and the potential for taxpayer fraud. ${ }^{71}$ Under a marriage-neutral system of mandatory separate filing, the spouse who actually incurs an expense would, ideally, be entitled to the deduction or exemption associated with it. But many of the expenses for which exemptions and deductions are allowed, such as those for jointly owned property or the support of children, are incurred and paid jointly by both spouses, and keeping records of such expenditures would be difficult. Moreover, married persons could arrange fraudulent transfers of some deductions and credits far more easily than fraudulent transfers of title to income-producing assets. ${ }^{72}$

Those problems might be best addressed by adopting two different allocation rules for two categories of expenses. Expenses clearly associated with property or income to which one spouse has title, such as depreciation deductions for rental property owned by one spouse, present few administrative problems and should be attributed to the spouse with title. ${ }^{73}$ Other types of exemptions and deductions present greater administrative and tax avoidance problems, and should be allocated according to an arbitrary rule. Examples are deductions and exemptions associated with jointly held property, such as capital gains exclusions on the sale of a residence; expenses that arise out of joint obligations, such as dependent's exemptions for child support; and expenses that are difficult to trace, such as personal property casualty losses and charitable contributions. Such expenses could be allocated entirely to the greater- or lesser-earning spouse, on a fifty-fifty basis, or in proportion to the income reported by each spouse. $^{74}$

70. If the administrative problems proved too great for the tax administration after the adoption of separate filing, an arbitrary rule, could be adopted. One commentator has suggested that, as unearned income accounts for only $10 \%$ of total adjusted gross income, adopting an arbitrary rule would not be a serious deviation from marriage neutrality for most taxpayers. Munnell, supra note 3, at 274.

71. Deductions were itemized on $26 \%$ of all tax returns in 1977. Munnell, supra note 3 , at 277 n.42. Even those taxpayers who do not itemize are entitled to claim dependents' exemptions and the childcare credit. The proper allocation of deductions and exemptions thus might have a much broader impact on tapxayers than the allocation of unearned income.

72. The question of allocating deductions, credits, and exemptions also arises under present law when married taxpayers file separately. Because only about $1.3 \%$ of all married couples file separately, however, few controversies have arisen. JOINT COMAITTEE ON TAXITION, supra note 2, at 38, 48.

73. This category would include capital loss deductions, capital gain exclusions on the sale of a residence, and investment credits.

74. As allocation entirely to the lesser- or greater-earning spouse inevitably recreates a marriage 


\section{Conclusion}

Despite its undesirable effects, joint filing has been retained because of the belief that, as a matter of horizontal equity, married couples with the same aggregate incomes should pay the same tax. Studies of marital behavior suggest that the income-pooling premise at the heart of this equity principle is invalid, and there is no compelling justification for the continued sacrifice of marriage neutrality and the failure to eliminate the second earner's disincentive. Congress therefore should adopt mandatory separate filing and return to the individual as the appropriate taxable unit.

\footnotetext{
bonus or penalty whenever the relevant expenses were not incurred by that spouse, a fifty-fifty or prorata rule might be preferable. While these rules might also violate marriage neutrality, they would do so in a less predictable fashion; the marriage penalty or bonus would vary from year to year depending on the proportions in which each spouse earned income and actually incurred deductible expenses. Such rules are therefore less likely to create clearly perceived incentives or disincentives for marriage.

Whatever rule is adopted would have to require that if one spouse itemizes, the other must do so as well, to prevent all itemized deductions from being reported on the return of one spouse while the other takes advantage of the zero bracket amount. If one spouse earns insufficient income to file a separate return, the other might be granted an additional dependent's exemption.
} 